\title{
Friedmanniella luteola sp. nov., Friedmanniella lucida sp. nov., Friedmanniella okinawensis sp. nov. and Friedmaniella sagamiharensis sp. nov., isolated from spiders
}

\author{
Kimika Iwai, Kazuo Aisaka and Makoto Suzuki†
}

Correspondence

Kimika Iwai

kimika.iwai@kyowa-kirin.co.jp
Innovative Drug Research Laboratories, Kyowa Hakko Kirin Co., Ltd 3-6-6, Asahi-machi, Machidashi, Tokyo 194-8533, Japan

Four Gram-positive, non-motile, aerobic actinobacteria were isolated from spiders and their webs. Their genetic, phenotypic and chemical properties were studied. The 16S rRNA gene sequence data suggested that the four novel isolates belonged to the genus Friedmanniella. Two strains $\left(\mathrm{FA} 1^{\top}\right.$ and $\mathrm{FA} 2^{\top}$ ) formed a cluster together with Friedmanniella capsulata and Friedmanniella lacustris and the other two strains (FB1 ${ }^{\top}$ and $\mathrm{FB} 2^{\top}$ ) formed a cluster together with Friedmanniella antarctica and Friedmanniella spumicola. The cell-wall peptidoglycan contained LL- $\mathrm{A}_{2} \mathrm{pm}$ and mycolic acids were absent. Isoprenoid quinones were mainly composed of MK-9(H4), MK-9(H2) and MK-9 and the predominant fatty acids were 12-methyltetradecanoic acid (ai- $\mathrm{C}_{15: 0}$ ) and 13methyltetradecanoic acid ( $\mathrm{i}-\mathrm{C}_{15: 0}$ ). The major polar lipids were phosphatidylinositol and phosphatidylglycerol. In addition, strain $\mathrm{FA} 1^{\top}, \mathrm{FB}^{\top}$, and $\mathrm{FB} 2^{\top}$ contained diphosphatidylglycerol and phosphatidylcholine. The DNA G +C contents were: $72 \mathrm{~mol} \%, 73 \mathrm{~mol} \%, 74 \mathrm{~mol} \%$ and 75 mol\% for strains $F A 1^{\top}, F A 2^{\top}, F B 1^{\top}$, and $F B 2^{\top}$, respectively. DNA-DNA hybridization studies demonstrated that the novel strains showed low relatedness values to $F$. capsulata, F. lacustris, $F$. antarctica and $F$. spumicola. These data support the proposal that strains $\mathrm{FA} 1^{\top}, \mathrm{FA} 2^{\top}, \mathrm{FB} 1^{\top}$ and FB2 ${ }^{\top}$ represent novel species of the genus Friedmanniella. Therefore, the names Friedmanniella luteola (type strain $\mathrm{FA1} 1^{\top}=\mathrm{DSM} 21741^{\top}=\mathrm{NBRC} 104963^{\top}$ ), Friedmanniella lucida (type strain $\mathrm{FA} 2^{\top}=\mathrm{DSM} 21742^{\top}=\mathrm{NBRC} 104964^{\top}$ ), Friedmanniella okinawensis (type strain $\mathrm{FB} 1^{\top}=\mathrm{DSM}$ $21744^{\top}=$ NBRC $104966^{\top}$ ) and Friedmanniella sagamiharensis (type strain $\mathrm{FB} 2^{\top}=\mathrm{DSM}$ $21743^{\top}=$ NBRC $104965^{\top}$ ) are proposed for these new strains.
During a search for new secondary metabolites, actinobacteria other than the genus Streptomyces were investigated as potential producing strains. Spiders and their webs were chosen as an alternative to soil samples as they are easy to collect and have not thus far been used for microbe isolation. Isolates typical of the genus Friedmanniella were obtained at high frequency from spiders and four strains were selected for further analyses.

tPresent address: Kyowa Hakko Bio Co., Ltd, 1-6-1 Ohtemachi, Chiyoda-ku, Tokyo 100-8185, Japan.

Abbreviations: 2D TLC, two-dimensional thin layer chromatography, LL$\mathrm{A}_{2} \mathrm{pm}$, LL-diaminopimelic acid; SEM, scanning electron microscopy.

The GenBank/EMBL/DDBJ accession numbers for the 16S rRNA gene sequences of strains $F A 1^{\top}\left(=\mathrm{A} 341^{\top}\right), \quad F A 2^{\top}\left(=\mathrm{M} 28^{\top}\right), \quad F B 1^{\top}$ $\left(=04 \_4^{\top}\right)$ and $\mathrm{FB}^{\top}\left(=\mathrm{S} 20 \_27^{\top}\right)$ are AB445453-AB445456, respectively.

A supplementary table detailing the polar lipid properties for the spider isolates is available with the online version of this paper.
The genus Friedmanniella, containing LL-diaminopimelic acid $\left(\mathrm{LL}_{-} \mathrm{A}_{2} \mathrm{pm}\right)$ as the diagnostic cell-wall diamino acid, was first established by Schumann et al. (1997) as a member of the family Nocardioidaceae. At present, the genus contains four recognized species. Friedmanniella antarctica was isolated from Antarctic sandstone (Schumann et al., 1997), Friedmanniella spumicola and Friedmanniella capsulata were isolated from activated sludge samples (Maszenan et al., 1999) and Friedmanniella lacustris was reported from a hypersaline Antarctic lake (Lawson et al., 2000). In this paper, four novel actinobacterial isolates from spiders are described as novel species of the genus Friedmanniella.

All spider samples were collected in a Japanese forest. Spider webs were placed on HV agar [in a litre distilled water: $1.0 \mathrm{~g}$ humic acid, $0.5 \mathrm{~g} \mathrm{Na}_{2} \mathrm{HPO}_{4}, 1.71 \mathrm{~g} \mathrm{KCl}, 0.05 \mathrm{~g}$ $\mathrm{MgSO}_{4} \cdot 7 \mathrm{H}_{2} \mathrm{O}, 0.01 \mathrm{~g} \mathrm{FeSO}_{4} .7 \mathrm{H}_{2} \mathrm{O}, 0.02 \mathrm{~g} \mathrm{CaCO}_{3}, 1.0 \mathrm{ml}$ $\mathrm{B}$ vitamin mixture $(50 \mathrm{mg}$ thiamin $-\mathrm{HCl}, 50 \mathrm{mg}$ riboflavin, $50 \mathrm{mg}$ niacin, $50 \mathrm{mg}$ pyridoxin- $\mathrm{HCl}, 50 \mathrm{mg}$ inositol, $50 \mathrm{mg}$ calcium pantothenate, $50 \mathrm{mg} p$-aminobenzoic acid, 
$25 \mathrm{mg}$ biotin in $100 \mathrm{ml}$ distilled water), $18.0 \mathrm{~g}$ agar; pH 7.2] (Hayakawa \& Nonomura, 1987; Hayakawa et al., 2000) with antibiotics (cycloheximide $100 \mathrm{mg} \mathrm{l}^{-1}$, nystatin $50 \mathrm{mg} \mathrm{l}^{-1}$, nalidixic acid $10 \mathrm{mg} \mathrm{l}^{-1}$ and trimethoprim $\left.20 \mathrm{mg} \mathrm{l}^{-1}\right)$. Alternatively, a spider was allowed to walk over an agar plate. The plate surface was then sprayed twice with $2 \mathrm{ml} 70 \%$ ethanol to inhibit the growth of other bacteria and fungi. After spraying, the spider web was dissolved and the remaining material was spread until dry. The plates were incubated aerobically at $28{ }^{\circ} \mathrm{C}$ for 3 weeks. Culture purification and cell biomass preparation were conducted using KM398 medium (5 g glucose, 5 g soluble starch, $1.5 \mathrm{~g}$ beef extract, $2.5 \mathrm{~g}$ yeast extract, $2.5 \mathrm{~g}$ tryptone peptone (Difco), $0.5 \mathrm{~g} \mathrm{MgSO}_{4} \cdot 7 \mathrm{H}_{2} \mathrm{O}, 1 \mathrm{~g} \mathrm{KH}_{2} \mathrm{PO}_{4}, 0.5 \mathrm{~g}$ $\mathrm{Mg}_{3}\left(\mathrm{PO}_{4}\right)_{2} \cdot 8 \mathrm{H}_{2} \mathrm{O}, 1 \mathrm{l}$ distilled water, $\left.\mathrm{pH} 7.2\right)$ at $25^{\circ} \mathrm{C}$ for 14 days and the biomass was used for chemotaxonomic studies. The isolates were preserved in $20 \%$ glycerol solution at $-80{ }^{\circ} \mathrm{C}$ until use. Strain $\mathrm{FAl}^{\mathrm{T}}$ was isolated from the surface of the body of a specimen of the spider Diaea subdola collected in Yamanashi prefecture, Japan. Strains $\mathrm{FA} 2^{\mathrm{T}}, \mathrm{FB}^{\mathrm{T}}$ and $\mathrm{FB} 2^{\mathrm{T}}$ were isolated from spiders' silk or web. Strain $\mathrm{FA} 2^{\mathrm{T}}$ was isolated from Agelena silvatica (Tokyo), strain $\mathrm{FB1}^{\mathrm{T}}$ was from unidentified spider (Okinawa) and strain $\mathrm{FB} 2^{\mathrm{T}}$ was from Agelena silvatica (Kanagawa). The strains used for comparison were $F$. antarctica DSM $11053^{\mathrm{T}}$, F. lacustris DSM $11465^{\mathrm{T}}$ and F. capsulata DSM $12936^{\mathrm{T}}$. Due to problems in the acquisition of F. spumicola ACM $5121^{\mathrm{T}}$, only previously published data were used for comparisons for this species.

PCR amplification of the 16S rRNA gene of the isolates from spiders was carried out following the methods of Tanner et al. (2000). The amplified fragments were purified by a MagExtractor kit (Toyobo). Sequencing was carried out with a BigDye Terminator Cycle Sequencing FS Ready Reaction kit and an ABI 377 DNA sequencer (Applied Biosystems). The partial sequences (1420 bp) of the $16 \mathrm{~S}$ rRNA gene were aligned using MEGA4.0 software (Tamura et al., 2007). Genomic DNA preparation, DNA G+C content determination and DNA-DNA hybridization experiments were conducted according to Suzuki et al. (1999, 2001).

For scanning electron microscopy (SEM) observations, the strains were cultured on $1 / 2 \mathrm{HV}$ (containing half the usual amount of humic acid) agar for $14-21$ days at $25^{\circ} \mathrm{C}$. An agar block containing strain growth was fixed with osmium tetroxide vapour, washed with distilled water, dehydrated through a graded ethanol series, transferred into amylacetate and finally critical-point dried with liquid carbon dioxide (HCP-2; Hitachi). The specimens were sputtercoated with platinum-palladium (E-102; Hitachi) and observed via scanning electron microscopy (S-570LB; Hitachi).

Cell-wall diamino acids were analysed as described by Staneck \& Roberts (1974) and cell wall acyl type was determined as described by Uchida et al. (1999). Purified cell walls were obtained using the method of Kawamoto et al. (1981), and the amino acid composition of hydrolysed cell walls was determined using cellulose TLC with n-butanol/acetic acid/ $\mathrm{H}_{2} \mathrm{O}(4: 1: 2)$ as the development system (Matsumoto et al., 2007). Absence of mycolic acids was demonstrated following Yano et al. (1972). Cellular fatty acid profiles were determined as described by Miller (1982) with a GC-2010 (Shimadzu) and the authentic standards (Bacterial Acid Methyl Esters CP Mix; Matreya Inc.). Menaquinones were extracted following Collins et al. (1977) and the molecular species were determined by HPLC (Tamaoka et al., 1983). Polar lipids were extracted according to the method of Minnikin et al. (1984) and analysed by MS as described by Taguchi et al. (2000). Matrix-assisted laser desorption/ionisationtime of flight mass spectrometry (MALDI-TOF MS) was used to perform the assignment of the head group by the position sensitive detector (PSD) measurement. Molecular species and the length of the acyl chain were identified from the retention time and mass spectrum with LC/ESI (electro spray ionization).

All physiological tests were performed at $25{ }^{\circ} \mathrm{C}$ unless otherwise stated. The cell suspensions for inoculation were prepared with 10 day cultures on KM398 agar at $25{ }^{\circ} \mathrm{C}$. Growth at different temperatures (between $6-37{ }^{\circ} \mathrm{C}$ ), $\mathrm{NaCl}$ concentrations $(0-10 \%$ at intervals of $2 \%, \mathrm{w} / \mathrm{v})$ and $\mathrm{pH}$ (5.0-9.0 at intervals of $0.5 \mathrm{pH}$ unit) were determined on KM398 agar or broth. Carbon source utilization was determined using ISP 9 medium (Pridham \& Gottlieb, 1948) supplemented with $0.05 \%$ yeast extract, $1 \mathrm{ml} \mathrm{l}^{-1}$ of B vitamins (Hayakawa et al., 2000) and $1 \%(\mathrm{w} / \mathrm{v})$ of each substrate. Aerobic reduction of nitrate to nitrite or $\mathrm{N}_{2}$, urease activity, protease activity, production of indole and acid production from glucose were assessed by API 20NE systems (bioMérieux). Catalase production was evaluated by the evolution of bubbles from $3 \% \mathrm{H}_{2} \mathrm{O}_{2}$. Cytochrome oxidase activities were tested with cytochrome oxidase reagent (Nissui Pharmaceutical). Production of hydrogen sulfide from peptone was evaluated following the method of Tresner \& Danga (1958). Starch hydrolysis was tested by observing the appearance of clear zones on inorganic saltsstarch agar (ISP 4), following Goodfellow \& Pirouz (1982). The biochemical characteristics of all strains were determined using API 20NE kits (bioMérieux).

Samples derived from spiders usually contain many kinds of fast-growing bacteria and fungi and the pre-treatment method using $70 \%$ ethanol effectively prevented their growth. Members of the genus Friedmanniella and other actinobacteria seemed to show tolerance to $70 \%$ ethanol since diverse actinobacteria (including members of the genus Friedmanniella) were observed after this treatment. A total of 1159 actinobacterial strains were obtained from 244 spider samples and the strains included representatives from at least 29 genera (Iwai et al., 2009). Members of the suborder Propionibacterineae, such as the genera Friedmanniella and Microlunatus, appeared to be abundant in the samples from spiders as compared to isolates obtained from soil samples. The percentage of representa- 
tives of the genus Friedmanniella in the 1159 actinobacterial strains was about $2 \%$. Friedmanniella-like strains were acquired from funnel-webs, orb webs, tangle-webs and crab spiders (non-web-producers) with high frequency. This study focused on members of the genus Friedmanniella and the four unique strains that were identified. The species of the genus Friedmanniella described previously have been isolated from so-called harsh environments, but we could effectively isolate them from spiders and their webs after pretreatment with $70 \%$ ethanol. A possible reason why species of the genus Friedmanniella have not been isolated previously from ordinary soil samples could be due to competition with other soil micro-organisms, such as members of the genus Streptomyces. The relative percentage of Friedmanniella species in soil is very low and it is very difficult to isolate them by a direct plating method. Members of the genus Friedmanniella are probably common in a wide range of environments. The reasons why species of the genus Friedmanniella have been isolated in this study could be that spider environments are particularly suitable for such species or because the pretreatment with $70 \%$ ethanol could inhibit the growth of other micro-organisms more than that of members of the genus Friedmanniella.

Phylogenetic analysis of the 16S rRNA gene sequences $(1441 \mathrm{bp})$ of strains $\mathrm{FAl}^{\mathrm{T}}, \mathrm{FA} 2^{\mathrm{T}}, \mathrm{FB}^{\mathrm{T}}$ and $\mathrm{FB} 2^{\mathrm{T}}$ revealed that the four strains formed a tight cluster with species of the genus Friedmanniella and were supported by a high bootstrap value of $100 \%$ (Fig. 1). Strains $\mathrm{FAl}^{\mathrm{T}}$ and $\mathrm{FA} 2^{\mathrm{T}}$ were most closely related to $F$. capsulata and $F$. lacustris, with sequence similarity levels of $>97 \%$, whereas strains $\mathrm{FB} 1^{\mathrm{T}}$ and $\mathrm{FB} 2^{\mathrm{T}}$ were most closely related to $F$. antarctica and F. spumicola, with sequence similarity levels of $>98 \%$. Strains $\mathrm{FAl}^{\mathrm{T}}$ and $\mathrm{FA} 2^{\mathrm{T}}, F$. capsulata and F. lacustris were therefore classified as Friedmanniella group A, whereas strains $\mathrm{FB}^{\mathrm{T}}$ and $\mathrm{FB} 2^{\mathrm{T}}, F$. antarctica and $F$. spumicola were classified as Friedmanniella group B, as shown in Fig. 1. These phylogenetic results strongly suggested that the isolates belong to the genus Friedmanniella.

All isolates were chrome yellow to orange in colour, nonmotile, slow-growing, Gram-positive and grew as clusters of coccoid cells, in which bunches of 2 or 4 cells were observed under the microscope (Fig. 2). Strains $\mathrm{FA}^{\mathrm{T}}, \mathrm{FB}^{\mathrm{T}}$ and $\mathrm{FB} 2^{\mathrm{T}}$ produced extracellular polymers after prolonged cultivation. Strain $\mathrm{FAl}^{\mathrm{T}}$ did not produce extracellular polymers and had crumbly colonies.

The cell-wall peptidoglycan of all four isolates contained LL- $\mathrm{A}_{2} \mathrm{pm}$ as the diagnostic diamino acid and the interpeptide bridges had a single glycine residue, at position 1 . These results were consistent with the type A $3 \gamma$ peptidoglycan, which is found in the genus Friedmaniella (Schleifer

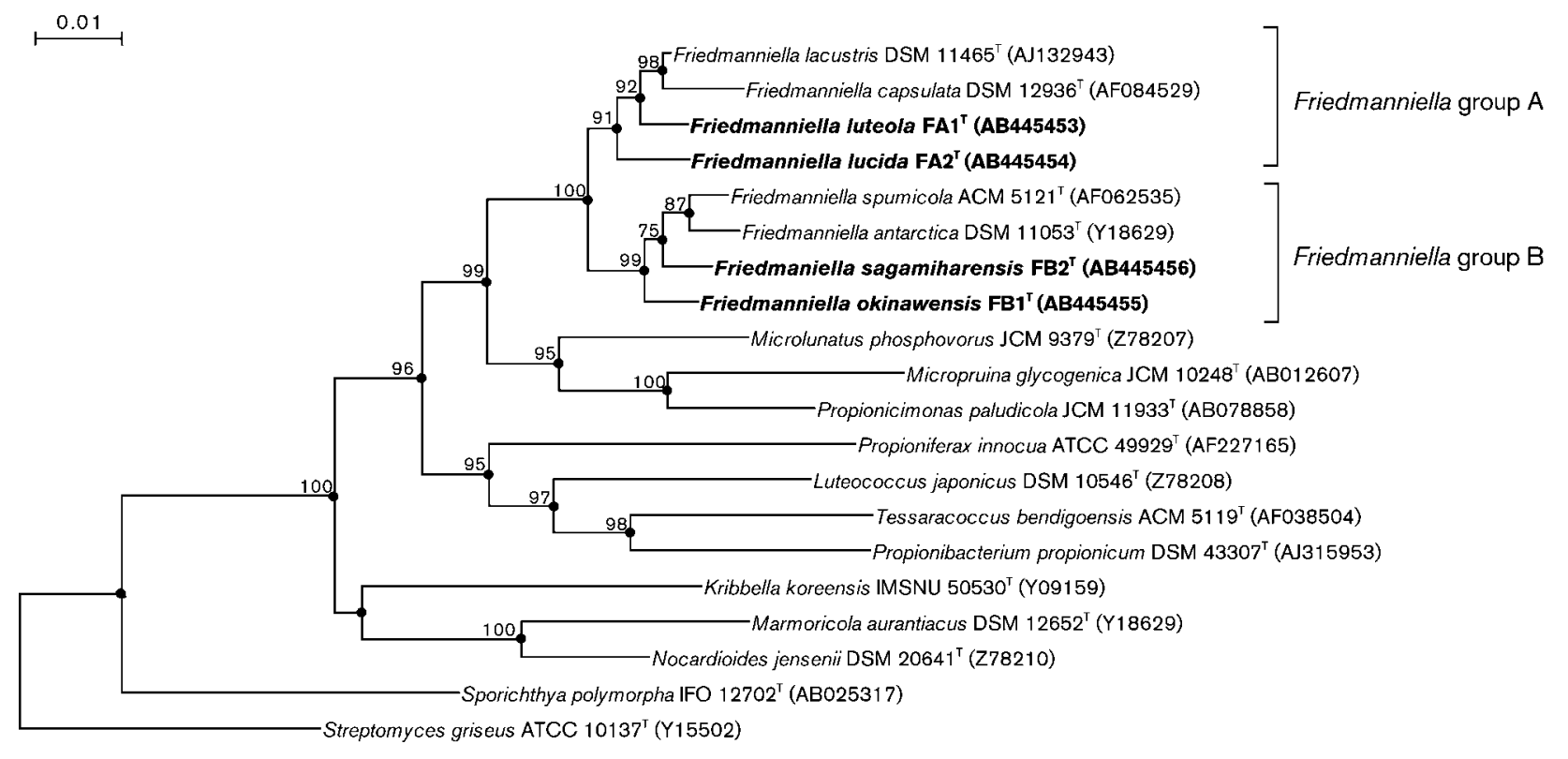

Fig. 1. Phylogenetic tree of the genus Friedmanniella and related actinomycetes based on $16 S$ rRNA gene sequences, constructed using the neighbour-joining method (Saitou \& Nei, 1987). Streptomyces griseus ATCC 10137 ${ }^{\top}$ (GenBank accession no. Y15501) was used as the outgroup. Filled circles indicate generic branches recovered with the maximumparsimony algorithm. Branches corresponding to partitions reproduced in $<60 \%$ bootstrap replicates are collapsed. The number at each node indicates the percentage bootstrap value of 1000 replicates (Felsenstein, 1985). Bar, genetic distance of $0.01\left(K_{\text {nuc }}\right)$. The evolutionary distances were computed using the Maximum Composite Likelihood method (Tamura et al., 2004) and are in units of number of base substitutions per site. All positions containing gaps and missing data were eliminated from the dataset (complete deletion option). There were a total of 1441 positions in the final dataset. Phylogenetic analyses were conducted in MEGA4 (Tamura et al., 2007). 

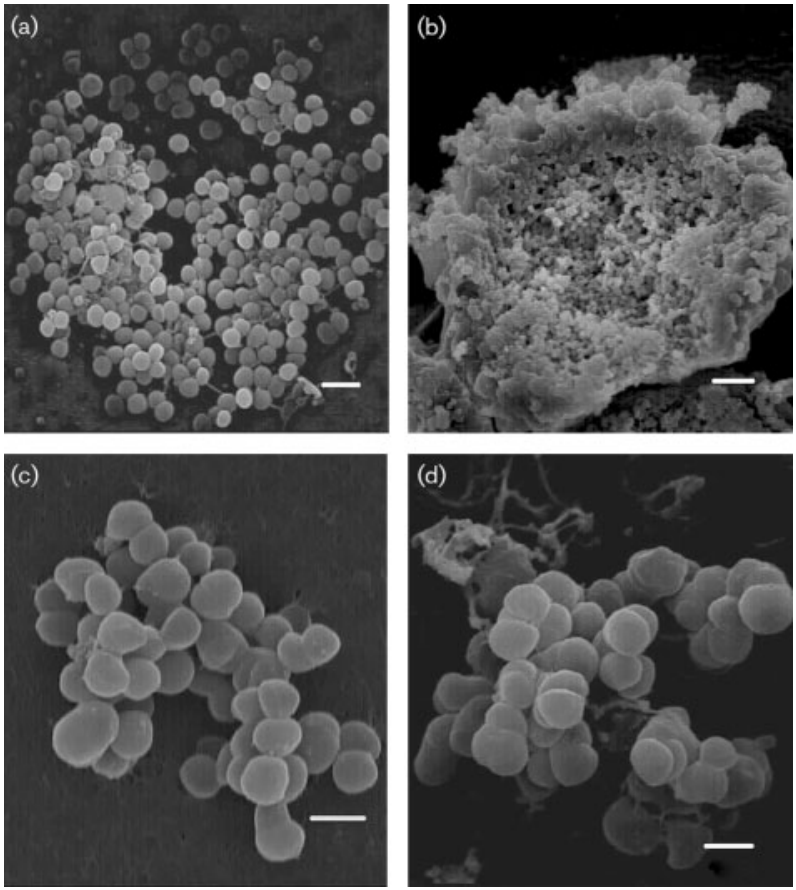

Fig. 2. SEM images of cells of strains $F A 1^{\top}, F A 2^{\top}, F B 1^{\top}$ and $F B 2^{\top}$ isolated from spiders. (a) Strain $F A 1^{\top}$ showing a colony of aggregated cells; (b) strain $\mathrm{FA}^{\top}{ }^{\top}$; (c) strain $\mathrm{FB} 1^{\top}$; (d) strain $\mathrm{FB} 2^{\top}$ showing regular packages associated into aggregates. Bars, (a) $2 \mu \mathrm{m}$; (b, c) $5 \mu \mathrm{m}$; (d) $1 \mu \mathrm{m}$.

\& Seidl, 1985). Mycolic acids were not detected. The cellular fatty acid profile of strain $\mathrm{FAl}^{\mathrm{T}}$ was characterized by the predominance of ai- $\mathrm{C}_{15: 0}$ (12-methyltetradecanoic acid; $71.3 \%), \quad \mathrm{i}-\mathrm{C}_{15: 0}$ (13-methyltetradecanoic acid; $26.8 \%$ ) and trace amounts of $\mathrm{C}_{16: 0}$ (methylhexadecanoic acid), i- $\mathrm{C}_{16: 0}$ (14-methylpentadecanoic acid) and $\mathrm{i}-\mathrm{C}_{17: 0}$ (15-methylhexadecanoic acid). Strains $\mathrm{FA}^{\mathrm{T}}$ and $\mathrm{FB} 1^{\mathrm{T}}$ showed similar fatty acid contents to strain $\mathrm{FAl}^{\mathrm{T}}$. Strain $\mathrm{FA}^{\mathrm{T}}$ contained ai- $\mathrm{C}_{15: 0}(60.6 \%)$ and $\mathrm{i}-\mathrm{C}_{15: 0}(37.1 \%)$ and strain $\mathrm{FB1}^{\mathrm{T}}$ had ai- $\mathrm{C}_{15: 0}(59.3 \%)$ and $\mathrm{i}-\mathrm{C}_{15: 0}(37.5 \%)$ as the dominant fatty acids. On the other hand, strain $\mathrm{FB}^{\mathrm{T}}$ was mainly composed of $\mathrm{i}-\mathrm{C}_{15: 0}(59.1 \%)$ and ai- $\mathrm{C}_{15: 0}(37.4 \%)$. Additional differences between the fatty acid contents of the four novel strains are shown in Table 1. Since the results of fatty acid analyses vary to some degree between laboratories and the methods used also differ to some extent, the fatty acid profiles of the type strains of the genus Friedmanniella were all determined under standardized conditions. Isoprenoid quinones were mainly composed of MK-9 $\left(\mathrm{H}_{4}\right)$, MK-9 $\left(\mathrm{H}_{2}\right)$ and MK-9. Strains FA1 ${ }^{\mathrm{T}}$ and $\mathrm{FB1}^{\mathrm{T}}$ had all three quinones at ratios of $67: 24: 9$ and $74: 21: 5$, respectively. Strain $\mathrm{FB} 2^{\mathrm{T}}$ had MK-9 $\left(\mathrm{H}_{4}\right)$ and MK- $9\left(\mathrm{H}_{2}\right)$ at a ratio of $77: 23$. Strain $\mathrm{FA}_{2}{ }^{\mathrm{T}}$ possessed only MK-9 $\left(\mathrm{H}_{4}\right)$. The four novel strains contained phosphatidylinositol and phosphatidylglycerol as the polar lipids. In addition, strains $F A 1^{\mathrm{T}}$, $\mathrm{FB}^{\mathrm{T}}$ and $\mathrm{FB}^{\mathrm{T}}$ also contained diphosphatidylglycerol and phosphatidylcholine. The existence of a previously unidentified phosphatidylcholine was demonstrated using MS for analysis of the polar lipids (see Supplementary Table S1 in IJSEM Online). The DNA G + C contents were $72 \mathrm{~mol} \%$ for strain $\mathrm{FAl}^{\mathrm{T}}, 73 \mathrm{~mol} \%$ for strain $\mathrm{FA} 2^{\mathrm{T}}, 74 \mathrm{~mol} \%$ for strain $\mathrm{FB}^{\mathrm{T}}$ and $75 \mathrm{~mol} \%$ for strain $\mathrm{FB} 2^{\mathrm{T}}$.

The results of the DNA-DNA hybridization analysis were as follows. In group $\mathrm{A}$, strains $\mathrm{FA} 1^{\mathrm{T}}$ and $\mathrm{FA} 2^{\mathrm{T}}$ showed only $29 \%$ and $43 \%$ relatedness to F. lacustris and F. capsulata, respectively. Strains $\mathrm{FAl}^{\mathrm{T}}$ and $\mathrm{FA} 2^{\mathrm{T}}$ showed $46 \%$ relatedness to each other. In group $\mathrm{B}$, strains $\mathrm{FB} 1^{\mathrm{T}}$ and $\mathrm{FB} 2^{\mathrm{T}}$ both showed $15 \%$ DNA-DNA relatedness to $F$. antarctica. Strains $\mathrm{FB}^{\mathrm{T}}$ and $\mathrm{FB} 2^{\mathrm{T}}$ showed $11 \%$ and $30 \%$ relatedness, respectively, to F. spumicola. Strains $\mathrm{FB}^{\mathrm{T}}$ and $\mathrm{FB} 2^{\mathrm{T}}$ showed only $19 \%$ relatedness to each other. These values were below the $70 \%$ cut-off point for species delineation recommended by Wayne et al. (1987). In addition, characteristics such as the mode of cell aggregation, DNA G $+\mathrm{C}$ contents and presence

Table 1. Cellular fatty acids contents of isolates $\mathrm{FA} 1^{\top}, \mathrm{FA} 2^{\top}, \mathrm{FB} 1^{\top}$ and $\mathrm{FB} 2^{\top}$ and recognized species of the genus Friedmanniella

Strains: $1, \mathrm{FAl}^{\mathrm{T}} ; 2, \mathrm{FA2}^{\mathrm{T}} ; 3$, F. lacustris DSM $11465^{\mathrm{T}} ; 4$, F. capsulata DSM $12936^{\mathrm{T}} ; 5, \mathrm{FB}^{\mathrm{T}} ; 6, \mathrm{FB}^{\mathrm{T}} ; 7$, F. spumicola ACM $5121^{\mathrm{T}} ; 8$, F. antarctica DSM $11053^{\mathrm{T}}$. All data from this study except for taxon 7, which are from Maszenan et al. (1999).

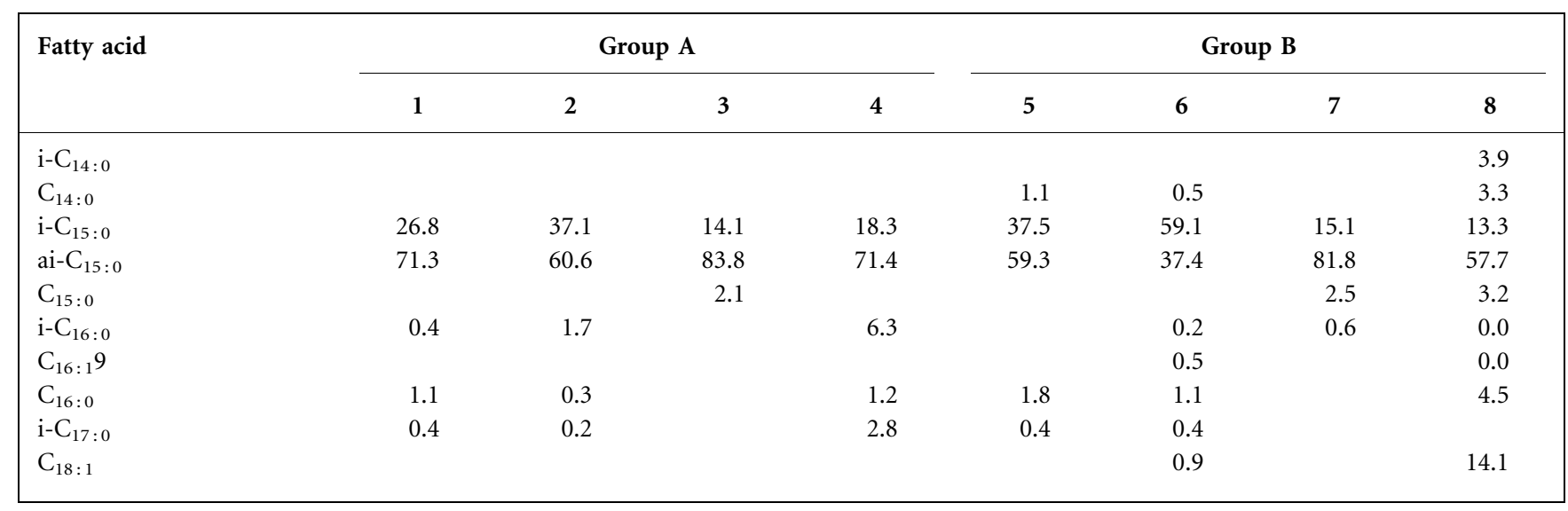


of phosphatidylcholine (except for strain $\mathrm{FA} 2^{\mathrm{T}}$ ) suggested that the four strains isolated from spiders were novel species of the genus Friedmanniella.

All isolates grew optimally at $25{ }^{\circ} \mathrm{C}$ and at $\mathrm{pH}$ 7.0. Strain $\mathrm{FAl}^{\mathrm{T}}$ was different from F. lacustris and F. capsulata as regards the utilization of raffinose and inositol and lack of utilization of xylose. Sains $\mathrm{FB}^{\mathrm{T}}$ and $\mathrm{FB}_{2}^{\mathrm{T}}$ differed from $F$. antarctica and F. spumicola in their utilization of rhamnose, sucrose, raffinose and inositol and did not produce hydrogen sulfide. DNA-DNA hybridization studies of $F$. spumicola with strains $\mathrm{FB}^{\mathrm{T}}$ and $\mathrm{FB} 2^{\mathrm{T}}$ are not described in this study. However, carbon source utilization data for strains $\mathrm{FB} 1^{\mathrm{T}}$ and $\mathrm{FB} 2^{\mathrm{T}}$ supported their differentiation from F. spumicola. Urease activity and the hydrolysis of gelatin were positive for all isolates. Catalase activity was positive for strains $F A 1^{\mathrm{T}}, F A 2^{\mathrm{T}}$ and $F B 1^{\mathrm{T}}$, but was negative for strain $\mathrm{FB} 2^{\mathrm{T}}$. Reduction of nitrate to nitrite, production of hydrogen sulfide and indole, oxidase activity, hydrolysis of starch and acid production from glucose were also negative for all strains. Other physiological and biochemical properties are listed in Table 2 and in the species

Table 2. Characteristics of isolates $F A 1^{\top}, F A 2^{\top}, F B 1^{\top}, F B 2^{\top}$ (group $A, B$ ) compared with related species of the genus Friedmanniella

Strains: 1, FA1 ${ }^{\mathrm{T}} ; 2$, FA2 ${ }^{\mathrm{T}} ; 3$, F. lacustris DSM $11465^{\mathrm{T}}$ (data from Lawson et al., 2000); 4, F. capsulata DSM $12936^{\mathrm{T}}$ (Maszenan et al., 1999); 5, FB1 ${ }^{\mathrm{T}}$; 6, $\mathrm{FB}^{\mathrm{T}}$; 7, Friedmanniella spumicola ACM 5121 ${ }^{\mathrm{T}}$ (Maszenan et al., 1999); 8, F. antarctica DSM 11053 ${ }^{\mathrm{T}}$ (Schumann et al., 1997). +, Positive; ,- negative; $\mathrm{w}$, weakly positive.

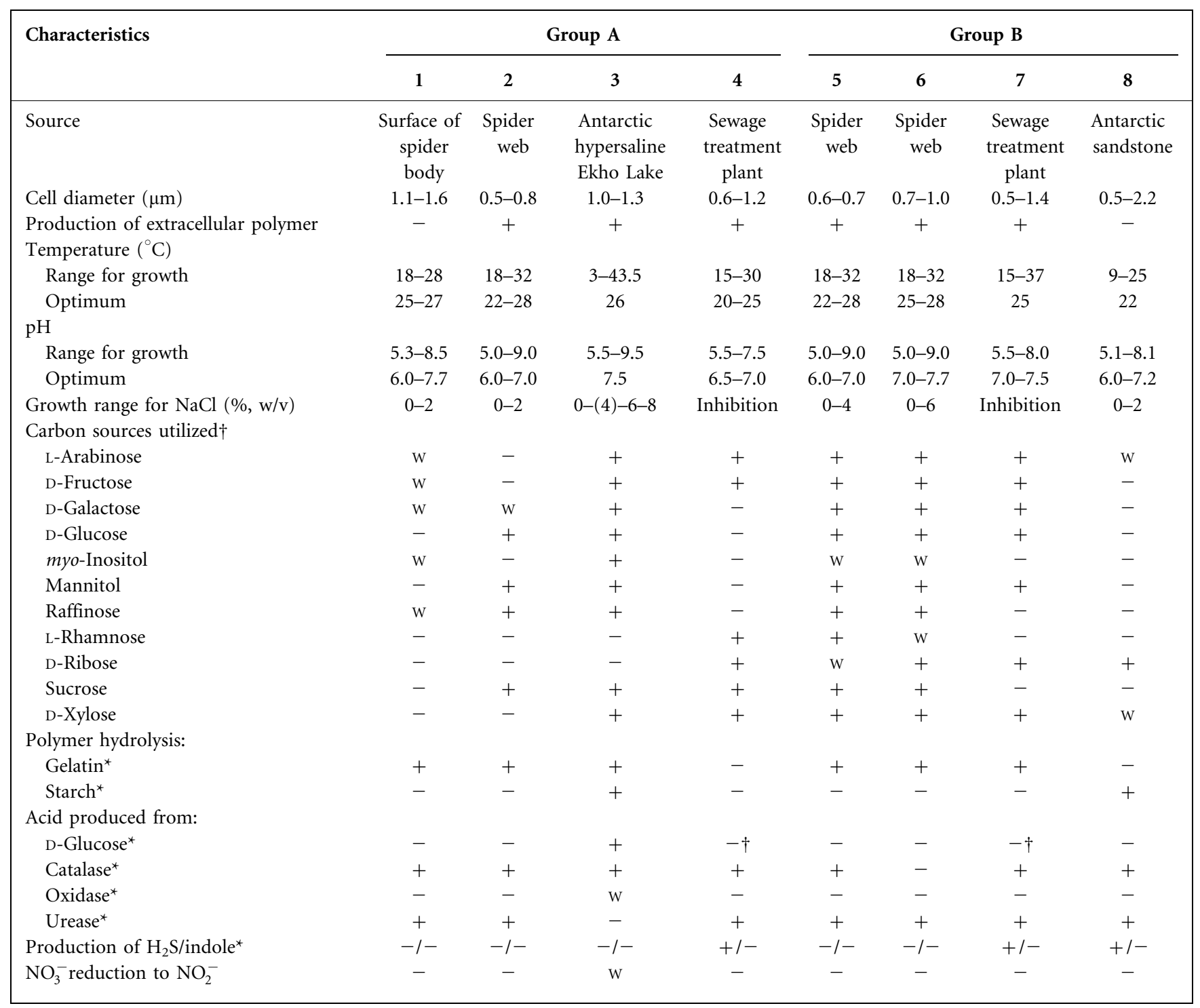

${ }^{\star}$ Results obtained by API $20 \mathrm{NE}$.

$\dagger$ Results obtained in this study. 
descriptions. The characteristics that differentiate the new strains isolated from spiders from the recognized species of the genus Friedmanniella are also presented.

In summary, the characteristics of these actinomycetes isolated from spiders were consistent with members of the genus Friedmanniella with regards to morphology, biochemistry and chemotaxonomy. However, their phenotypic, biochemical and chemotaxonomic characteristics were different from recognized species of the genus Friedmanniella (Tables 1, 2 and Supplementary Table S1). Low DNA-DNA relatedness values were detected between the new isolates and between the isolates and recognized species. From the results of this study, it is apparent that strains $F A 1^{\mathrm{T}}, \mathrm{FA} 2^{\mathrm{T}}, \mathrm{FB} 1^{\mathrm{T}}$ and $\mathrm{FB} 2^{\mathrm{T}}$ represent four separate novel species of the genus Friedmanniella, for which the names Friedmanniella luteola $\left(\right.$ strain $\mathrm{FA}^{\mathrm{T}}$ ), Friedmanniella lucida (strain $\mathrm{FA} 2^{\mathrm{T}}$ ), Friedmanniella okinawensis (strain $\mathrm{FB} 1^{\mathrm{T}}$ ) and Friedmanniella sagamiharensis (strain $\mathrm{FB} 2^{\mathrm{T}}$ ) are proposed.

\section{Description of Friedmanniella luteola sp. nov.}

Friedmanniella luteola (lu.te'o.la. L. fem. adj. luteola referring to the yellow colour of the colonies).

Coccoid cells are 1.1-1.6 $\mu \mathrm{m}$ in diameter with a smooth surface. The cells are arranged singly or in pairs and adhere to form clusters. The colony is crumbly. Growth in submerged, standing and shaking cultures is poor. Colonies grown aerobically on KM364 agar for 2 weeks are small, creamy yellow, convex and brittle. The temperature range for growth is $18-28{ }^{\circ} \mathrm{C}$ and optimum growth temperature is $25-27{ }^{\circ} \mathrm{C}$. Growth occurs at pH 5.38.5; the optimum $\mathrm{pH}$ range is $6.0-7.7 . \mathrm{NaCl}$ tolerance is up to $2 \%(\mathrm{w} / \mathrm{v})$; optimum growth occurs with no addition of $\mathrm{NaCl}$. Catalase-positive. Oxidase-negative. Urease-positive. Does not reduce nitrate to nitrite. No acid is produced from D-glucose. Gelatin is hydrolysed, but starch is not hydrolysed. Negative for production of hydrogen sulfide and indole. L-Arabinose, D-galactose, D-fructose, raffinose and myo-inositol are weakly utilized, but D-ribose, Dxylose, D-glucose, L-rhamnose, sucrose and D-mannitol are not utilized. Predominant cellular fatty acids are ai- $C_{15: 0}$ and $\mathrm{i}-\mathrm{C}_{15: 0}$ and MK-9 $\left(\mathrm{H}_{4}\right)$, MK-9 $\left(\mathrm{H}_{2}\right)$, MK-9 are the major menaquinones. Polar lipids are phosphatidylglycerol, phosphatidylinositol, phosphatidylcholine and diphosphatidylglycerol. Diacylglycerol dihexose is another neutral lipid. Mycolic acids are absent.

The type strain, $\mathrm{FAl}^{\mathrm{T}}\left(=\mathrm{DSM} 21741^{\mathrm{T}}=\mathrm{NBRC} 104963^{\mathrm{T}}\right)$, was isolated from the surface of the spider Diaea subdola from Yamanashi Prefecture, Japan. The DNA G+C content of the type strain is $72 \mathrm{~mol} \%$.

\section{Description of Friedmaniella lucida sp. nov.}

Friedmanniella lucida (lu'ci.da. L. fem. adj. lucida brilliant, shining, referring to the shiny colony surface).
Coccoid cells are $0.5-0.8 \mu \mathrm{m}$ in diameter with a smooth surface. Cells are arranged in regular packets that adhere to form clusters. Growth in submerged, standing and shaking cultures is poor. Colonies grown aerobically on KM364 agar for 2 weeks are creamy yellow. The colony surface is crumbly, convex, watery and shiny depending on the growth medium. The temperature range for growth is 18 $32{ }^{\circ} \mathrm{C}$; optimum growth temperature is $22-28{ }^{\circ} \mathrm{C}$. Growth occurs at $\mathrm{pH}$ 5.0-9.0; optimum $\mathrm{pH}$ range is $5.0-7.0 . \mathrm{NaCl}$ tolerance up to $2 \%(\mathrm{w} / \mathrm{v})$, optimum growth occurs with no addition of $\mathrm{NaCl}$. Catalase-positive. Oxidase-negative. Urease-positive. Does not reduce nitrate to nitrite. No acid is produced from D-glucose. Gelatin is hydrolysed, but starch is not hydrolysed. Negative for production of hydrogen sulfide and indole. D-Glucose, D-galactose (weakly), sucrose, raffinose and D-mannitol are utilized. L-Arabinose, D-ribose, D-xylose, D-fructose, L-rhamnose and myo-inositol are not utilized. Predominant cellular fatty acids are ai- $\mathrm{C}_{15: 0}, \mathrm{i}-\mathrm{C}_{15: 0}$ and $\mathrm{i}-\mathrm{C}_{16: 0}$. The major menaquinone is MK- $9\left(\mathrm{H}_{4}\right)$. Polar lipids are phosphatidylglycerol and phosphatidylinositol. Mycolic acids are absent.

The type strain, $\mathrm{FA}^{\mathrm{T}}\left(=\mathrm{DSM} 21742^{\mathrm{T}}=\right.$ NBRC $\left.104964^{\mathrm{T}}\right)$, was isolated from the web of the spider Agelena silvatica from Mitake ravine, Tokyo, Japan. The DNA G + C content of the type strain is $73 \mathrm{~mol} \%$.

\section{Description of Friedmaniella okinawensis sp. nov.}

Friedmanniella okinawensis (o.ki.na.wens' is. N.L. fem. adj. okinawensis pertaining to Okinawa, a prefecture in Japan, where the organism was first isolated).

Coccoid cells are $0.6-0.7 \mu \mathrm{m}$ in diameter with a smooth surface. Cells are arranged in regular packets that adhere to form clusters. Growth in submerged, standing and shaking cultures is poor. Colonies grown aerobically on KM364 agar for 2 weeks are orange. The colony surface is convex, watery and spread-out depending on the growth medium. The temperature range for growth is $18-32{ }^{\circ} \mathrm{C}$; the optimum growth temperature is $22-28{ }^{\circ} \mathrm{C}$. Growth occurs at $\mathrm{pH} 5.0-9.0$; optimum $\mathrm{pH}$ is $6.0-7.0 . \mathrm{NaCl}$ tolerance is up to $4 \%(\mathrm{w} / \mathrm{v})$; optimum growth occurs with no addition of $\mathrm{NaCl}$. Catalase-positive. Oxidase-negative. Urease-positive. Does not reduce nitrate to nitrite. No acid is produced from D-glucose. Gelatin is hydrolysed, but starch is not hydrolysed. Negative for production of hydrogen sulfide and indole. L-Arabinose, D-ribose (weakly), Dxylose, D-glucose, D-galactose, D-fructose, L-rhamnose, sucrose, raffinose, myo-inositol (weakly) and D-mannitol are utilized. Predominant cellular fatty acids are: ai- $\mathrm{C}_{15: 0}$, $\mathrm{i}-\mathrm{C}_{15: 0}, \mathrm{i}-\mathrm{C}_{16: 0}$ and $\mathrm{i}-\mathrm{C}_{17: 0}$, and the major menaquinones are MK-9 $\left(\mathrm{H}_{4}\right)$, MK-9 $\left(\mathrm{H}_{2}\right)$ and MK-9. Polar lipids are phosphatidylglycerol, phosphatidylinositol, phosphatidylcholine and diphosphatidylglycerol. Mycolic acids are absent.

The type strain, $\mathrm{FB}^{\mathrm{T}}\left(=\mathrm{DSM} 21744^{\mathrm{T}}=\right.$ NBRC $\left.104966^{\mathrm{T}}\right)$, was isolated from an unidentified orb web spider from 
Okinawa Prefecture, Japan. The DNA G $+\mathrm{C}$ content of the typestrain is $74 \mathrm{~mol} \%$.

\section{Description of Friedmaniella sagamiharensis sp. nov.}

Friedmaniella sagamiharensis (sa.ga.mi.ha.ren'sis. N.L. fem. adj. sagamiharensis pertaining to Sagamihara, a city in Japan, where the organism was first isolated).

Coccoid cells are $0.7-1.0 \mu \mathrm{m}$ in diameter with a smooth surface. Cells are arranged in pairs or groups of four and adhere to form clusters. Growth in submerged, standing and shaking cultures is poor. Colonies grown aerobically on KM364 agar for 2 weeks are orange. The colony surface is crumbly and convex to watery (by production of extracellular polymer) and spread out depending on the growth medium. The temperature range for growth is 18 $32{ }^{\circ} \mathrm{C}$; the optimum growth temperature is $25-28{ }^{\circ} \mathrm{C}$. Growth occurs at $\mathrm{pH}$ 5.0-9.0 and the optimum $\mathrm{pH}$ is 7.0 7.7. $\mathrm{NaCl}$ tolerance is up to $6 \%(\mathrm{w} / \mathrm{v})$, optimal growth occurs with no addition of $\mathrm{NaCl}$. Catalase and oxidasenegative. Urease-positive. Does not reduce nitrate to nitrite. No acid is produced from D-glucose. Gelatin is hydrolysed, but starch is not hydrolysed. Negative for production of hydrogen sulfide and indole. L-Arabinose, Dribose, D-xylose, D-glucose, D-galactose, D-fructose, Lrhamnose (weakly), sucrose, raffinose, myo-inositol (weakly) and D-mannitol are utilized. Predominant cellular fatty acids are $\mathrm{i}-\mathrm{C}_{15: 0}$ and ai- $\mathrm{C}_{15: 0}$, and the major menaquinones are MK-9 $\left(\mathrm{H}_{4}\right)$ and MK- $9\left(\mathrm{H}_{2}\right)$. Polar lipids are: phosphatidylglycerol, phosphatidylinositol, phosphatidylcholine and diphosphatidylglycerol. Diacylglycerol dihexose is another neutral lipid. Mycolic acids are absent.

The type strain, $\mathrm{FB}^{\mathrm{T}}\left(=\mathrm{DSM} 21743^{\mathrm{T}}=\mathrm{NBRC} 104965^{\mathrm{T}}\right)$, was isolated from the web of the spider Agelena silvatica collected from Kanagawa Prefecture, Japan. The DNA $\mathrm{G}+\mathrm{C}$ content of the type strain is $75 \mathrm{~mol} \%$.

\section{Acknowledgements}

We would like to thank the Tokyo Spider Study Group and the Arachnological Society of Japan. We would particularly like to thank Akira Shinkai and Akio Tanikawa for spider identification.

\section{References}

Collins, M. D., Pirouz, T., Goodfellow, M. \& Minnikin, D. E. (1977). Distribution of menaquinones in actinomycetes and corynebacteria. J Gen Microbiol 100, 221-230.

Felsenstein, J. (1985). Confidence limits on phylogenies: an approach using the bootstrap. Evolution 39, 783-791.

Goodfellow, M. \& Pirouz, T. (1982). Numerical classification of sporoactinomycetes containing meso-diaminopimelic acid in the cell wall. J Gen Microbiol 128, 503-527.

Hayakawa, M. \& Nonomura, H. (1987). Humic acid-vitamin agar, a new medium for selective isolation of soil actinomycetes. J Ferment Technol 65, 501-509.
Hayakawa, M., Otoguro, M., Takeuchi, T., Yamazaki, T. \& limura, Y. (2000). Application of a method incorporating differential centrifugation for selective isolation of motile actinomycetes in soil and plant litter. Antonie van Leeuwenhoek 78, 171-185.

Iwai, K., Iwamoto, S., Aisaka, K. \& Suzuki, M. (2009). Isolation of novel actinomycetes from spider materials. Actinomycetologica 23, 8-15.

Kawamoto, I., Oka, T. \& Nara, T. (1981). Cell wall composition of Micromonospora olivoasterospora, Micromonospora sagamiensis, and related organisms. J Bacteriol 146, 527-534.

Lawson, P. A., Collins, M. D., Schumann, P., Tindall, B. J., Hirsch, P. \& Labrenz, M. (2000). New LL-diaminopimelic acid-containing actinomycetes from hypersaline, heliothermal and meromictic Antarctic Ekho lake: Nocardioides aquaticus sp. nov. and Friedmannielly lacustris sp. nov. Syst Appl Microbiol 23, 219-229.

Maszenan, A. M., Sevior, R. J., Patel, B. K. C. \& Shumann, P. (1999). Friedmanniella spumicola sp. nov. and Friedmanniella capsulata sp. nov. from activated sludge foam: gram-positive cocci that grow in aggregates of repeating groups of cocci. Int J Syst Bacteriol 49, 1667-1680.

Matsumoto, A., Takahashi, Y., Fukumoto, M. \& Omura, S. (2007). Actinocatenispora sera sp. nov., isolated by long-term culturing. Int $J$ Syst Evol Microbiol 57, 2651-2654.

Miller, L. T. (1982). Single derivatization method for routine analysis of bacterial whole-cell fatty acid methyl esters, including hydroxy acids. J Clin Microbiol 16, 584-586.

Minnikin, D. E., O'Donnell, A. G., Goodfellow, M., Alderson, G., Athalye, M., Schaal, A. \& Parlett, J. H. (1984). An integrated procedure for the extraction of bacterial isoprenoid quinones and polar lipids. J Microbiol Methods 2, 233-241.

Pridham, T. G. \& Gottlieb, D. (1948). The utilization of carbon compounds by some Actinomycetales as an aid for species determination. J Bacteriol 56, 107-114.

Saitou, N. \& Nei, M. (1987). The neighbor-joining method: a new method for reconstructing phylogenetic trees. Mol Biol Evol 4, 406-425.

Schleifer, K. H. \& Seidl, P. H. (1985). Chemical composition and structure of murein. In Chemical Methods in Bacterial Systematics, pp. 201-219. Edited by M. Goodfellow \& D. E. Minnikin. London: Academic Press.

Schumann, P., Prauser, H., Rainey, F. A., Stackebrandt, E. \& Hirsch, P. (1997). Friedmanniella antarctica gen. nov., sp. nov., an LL-diaminopimelic acid containing actinomycete from Antarctic sandstone. Int $J$ Syst Bacteriol 47, 278-283.

Staneck, J. L. \& Roberts, G. D. (1974). Simplified approach to identification of aerobic actinomycetes by thin-layer chromatography. Appl Microbiol 28, 226-231.

Suzuki, M., Nakagawa, Y., Harayama, S. \& Yamamoto, S. (1999). Phylogenetic analysis of genus Marinilabilia and related bacteria based on the amino acid sequences of GyrB and emended description of Marinilabilia salmonicolor with Marinilabilia agarovorans as its subjective synonym. Int J Syst Bacteriol 49, 1551-1557.

Suzuki, M., Nakagawa, Y., Harayama, S. \& Yamamoto, S. (2001). Phylogenetic analysis and taxonomic study of marine cytophaga-like bacteria: proposal for Tenacibaculum gen. nov. with Tenacibaculum maritimum comb. nov. and Tenacibaculum ovolyticum comb. nov., and Tenacibaculum mesophilum sp. nov. and Tenacibaculum amylolyticum sp. nov. Int J Syst Evol Microbiol 51, 1639-1652.

Taguchi, R., Hayakawa, J., Takeuchi, Y. \& Ishida, M. (2000). Twodimensional analysis of phospholipids by capillary liquid chromatography/electrospray ionization mass spectrometry. J Mass Spectrom 35, 953-966.

Tamaoka, J., Katayama-Fujimura, Y. \& Kuraishi, H. (1983). Analysis of bacterial menaquinone mixtures by high performance liquid chromatography. J Appl Bacteriol 54, 31-36. 
Tamura, K., Nei, M. \& Kumar, S. (2004). Prospects for inferring very large phylogenies by using the neighbor-joining method. Proc Natl Acad Sci U S A 101, 11030-11035.

Tamura, K., Dudley, J., Nei, M. \& Kumar, S. (2007). MEGA4: Molecular evolutionary genetics analysis (MEGA) software version 4.0. Mol Biol Evol 24, 1596.

Tanner, M. A., Everett, C. L. \& Youvan, D. C. (2000). Molecular phylogenetic evidence for noninvasive zoonotic transmission of Staphylococcus intermedius from a canine pet to a human. J Clin Microbiol 38, 1628-1631.

Tresner, H. D. \& Danga, F. (1958). Hydrogen sulfate production by Streptomyces as a criterion for species differentiation. J Bacteriol 76, 239-244.
Uchida, K., Kudo, T., Suzuki, K. \& Nakase, T. (1999). A new rapid method of glycolate test by diethyl ether extraction, which is applicable to a small amount of bacterial cells of less than one milligram. J Gen Appl Microbiol 45, 49-56.

Wayne, L. G., Brenner, D. J., Colwell, R. R., Grimont, P. A. D., Kandler, O., Krichevsky, M. I., Moore, L. H., Moore, W. E. C., Murray, R. G. E. \& other authors (1987). International Committee on Systematic Bacteriology. Report of the ad hoc committee on reconciliation of approaches to bacterial systematics. Int J Syst Bacteriol 37, 463-464.

Yano, I., Saito, K., Fukukawa, Y. \& Kusunose, M. (1972). Structural analysis of molecular species of nocardomycolic acids from Nocardia erythropolis by the combined system of gas chromatography and mass spectrometry. FEBS Lett 21, 215-219. 